\title{
Cripteori: Var står den? Vart går den?
} som första gången lanserade begreppet 
"crip theory" - försiktigtvis i en fotnot - i en artikel från 2003:

As of this writing, the term crip theory has not gained wide recognition in the academy - or even among disability scholars in general though the term is in circulation. If I had my druthers, I would replace the term disability studies with crip theory or crip studies to represent its radical edge (51-52, n. 1).

Som framgår av citatet fanns ordet "crip" sedan länge bland amerikanska personer med funktionsnedsättning, men därifrån till att tala om "crip theory" var steget inte självklart.1 Ordet och begreppet fick sin stora spridning först genom Robert McRuers bok (2006). Och vad ligger i detta ord? I likhet med ordet "queer" är "crip" från början kränkande och nedvärderande. Enlig McRuer är det ett ord vars syfte är "att tala om för funktionshindrade att den här världen inte är till för dem, att de är mindervärdiga, att de är äckliga, att de aldrig kommer att kunna bli 'normala"' (McRuer 2005). Men precis som ordet queer har det inte översatts till något av de nordiska språken, vilket gör att det provokativa försvinner och därmed en del av dess berättigande på dessa språk. Och i och med att begreppet cripteori inte har haft samma exempellösa framgång som queerteori är det också mer instabilt. Likartade perspektiv definieras av olika forskare lika gärna som critical disability studies, feminist disability studies eller queer crip feminist studies (Hall 2015:10). På motsvarande sätt har andra forskare som inte identifierar sin forskning som crip theory eller crip studies bidragit med en teoriutveckling som är gemensam för en stor grupp forskare som utmanar "the social model". Så till exempel Rosemary GarlandThomsons definition av normaten (the normate), en neologism som “(...) names the veiled subject position of cultural self, the figure outlined by the array of deviant others whose marked bodies shore up the normate's boundaries". Den betecknar alltså de omärkta Första vars konturer bara antyds av de omärkta Andras kroppar, en maktposition, “(...) through which people can represent themselves as definitive human beings" (Garland-Thomson 1997: 8).

Forskningsvärlden. En strukturell förklaring till att queerteori lyckades där cripteori har misslyckats - eller i alla fall lyckats mindre bra - är att queerteori fyllde ut ett vacuum och svarade mot ett starkt känt behov. Den homosexuella rörelsen på 1970-talet var visserligen intellektuell i jämförelse med 1950talets diskreta homofila rörelse, men de lesbiska och gay-aktivister som verkade på 1970- och 1980-talen hade ännu inte erövrat universiteten. När Queer Nation-rörelsen på 1990-talet kunde kopplas samman med en generation forskare som publicerade banbrytande arbeten om kön och sexualitet (Butler 1990; Sedgwick 1990; Warner, red. 1994) fyllde den upp ett tomrum. Tidigare hade ingen inom universitetsvärlden utom läkare och psykologer intresserat sig för homosexualitet eller queera kulturella uttryck, men de nya queera forskarna red på en våg av intresse som genererades och fick näring av 1990-talets nyfeminism.

När cripteori föddes var situationen en annan. Det fanns redan en stark funktionshinderrörelse och en stark forskningstradition. Den internationella funktionshinderrörelsen hade genomgått en revolution på 1970-talet, när "the social model" formulerades i England och det relationella handikappbegreppet introducerades i Norden (Berg 2004). På 1990-talet förändrades funktionshindrades vardag radikalt i och med att Independent Living-rörelsens mångåriga arbete kröntes med framgång och personer med funktionsnedsättningar fick kontroll över sin assistans (Berg 2008; Wolmesjö \& Zanderin 2008; Höög et al. 2015). Dessutom rådde ingen brist på akademiskt intresse för funktionshinder: den samhällsvetenskapliga forskningen på området fyllde redan hyllmeter. När cripteori kom fyllde den alltså inte ut ett tomrum, 
och kunde heller inte räkna med att inspirera en akademisk rörelse som bestod av funktionshindrade själva - forskningsområdet var väl etablerat, men i Norden bestod det främst av icke-funktionshindrade forskare. I Storbritannien och USA hade många forskare själva funktionsnedsättningar, men i Storbritannien var de i allmänhet djupt förankrade $\mathrm{i}$ "the social model". I USA har cripteori rönt viss framgång, då framför allt bland cultural studies-forskare.

Just denna brist på forskare som själva har funktionsnedsättningar är en del av förklaringen till cripteorins brist på framgång $\mathrm{i}$ Norden. De forskare som ägnar sig åt funktionshinder saknar i allmänhet det aktivistiska perspektiv som är utmärkande för de flesta queerforskare. Visserligen är det inte nödvändigt att själv leva med en funktionsnedsättning för att forska om funktionshinder, men om hela gruppen forskare enbart består av normater, om en grupp forskar på en annan grupp, så reproduceras en kolonial situation och den brittiska funktionshinderrörelsens slagord "Nothing about us without us!" får ökad relevans. I en sådan situation blir det extra viktigt med allianser mellan forskarsamhället och funktionshinderrörelsen, men de stora funktionshinderorganisationerna verkar ha byggt fast sig i materiella förklaringsmodeller och den äldre generationen funktionshinderaktivister visar sig tämligen ointresserade av att förnya aktivismen genom de perspektiv som cripteori har att erbjuda.

\section{VAD KAN CRIPTEORI GÖRA SOM “THE SOCIAL MODEL" INTE KAN?}

Mycket av det cripteorin står för i McRuers tappning fanns alltså redan innan. Ett ifrågasättande av kategorin funktionshinder hade redan skett genom formuleringen av "the social model" eller det relationella handikappbegreppet. Vad som var nytt var den diskursiva tillgången till funktionshinder och idén om funktionshinder som iscensättning. Eftersom "the social model" är en materiell modell, som i första hand eller enbart - definierar funktionshindret som materiella faktorer i det omgivande samhället, negligeras ofta den levda erfarenheten av att ha en funktionsnedsättning. En värkande kropp, smärtor och ångest reduceras till individuella problem som funktionshinderrörelsen inte ska ägna sig åt ( $\mathrm{Si}$ ebers 2008; Patsavas 2014). Filosofen och genusforskaren Kim Q. Hall pekar på de risker som finns med en ensidig tillämpning av "the social model". Ett problem är att ett förnekande av den medicinska modellens relevans sviker de personer med funktionsnedsättning som söker bot och lindring. Ett annat är att "the social model" inte tar hänsyn till de olika komplicerade sätt som transpersoner ofta förhåller sig till en medicinsk diagnos (Kafer 2013; Spade 2003; Hall 2015).

Med cripteori fokuseras åter subjektblivandet i den moderna diskursen. Funktionhinder blir en iscensättning, en performativitet, som upprätthåller och reproducerar den maktskapande diskursen. McRuers begrepp "compulsory able-bodiedness", som han lånat från Adrienne Rich, gör det möjligt att ifrågasätta rådande maktordningar och destabilisera den rådande funktionsmaktordningen (Rich 1980; Bylund 2016). Praktiskt uttryckt så destabiliserar cripteorin gränsen mellan normater och funktionshindrade. Ett vanligt argument är att alla medborgare har behov av - och får - assistans i olika livssituationer. Assistans ges i form av barnpassning, sjukpenning och skolundervisning. Varför ska de assistansbehov som personer med funktionsnedsättning har placera dem i en särskild, stigmatiserad kategori? Varför kan inte personlig assistans betraktas som vilken behovsprövad social service som helst, som till exempel plats på förskola? En förälder behöver inte redogöra för försäkringskassan hur lång tid det tar för barnet att äta, medan funktionshindrade med assistansbehov måste ange på minuten hur lång tid det går åt för de enklaste göromål. Inte ens när 
småbarnsföräldrar fuskar och arbetar hemifrån när de har sjukpenning för "vård av sjukt barn" väcker det någon stor upprördhet. Men när missbruk av assistansersättningen upptäcks sätts hela reformen ifråga och försäkringskassans generaldirektör talar hotfullt om att fusket är utbrett och att "mörkertalet är stort" - det vill säga att hon inte vet hur många som fuskar men att det säkert är många (Begler 2015). För att upprätthålla funktionsmaktordningen och befästa att funktionshindrade är de Andra, bibehåller majoritetssamhället personlig assistans som en märkt kategori samhällsstöd förknippat med ett starkt stigma.

Stigmahantering är en annan av cripteorins starka sidor. Den "in your face"-attityd som cripteorin ger möjlighet till, den provokation den bär med sig, liknar vad Michael Warner har kallat en "stigmafil livsstil" (Warner 1999). Och i den stigmafila livsstilen, i synligheten, ligger nyckeln till mer tillgängligt samhälle, både materiellt och diskursivt. "Coming out crip" som McRuer diskuterar, handlar om att visa upp sitt stigma för världen och kräva rätten att ta plats. Som Sunaura Taylor kommenterar detta i Examined Life, det vid det här laget klassiska samtalet när hon och Judith Butler promenerar runt i San Francisco och diskuterar olika former av ömsesidigt beroende (Abrams 2011). Taylor karaktäriserar San Francisco som förmodligen det mest tillgängliga stället i världen:

“And partly what's so amazing to me about it is that the physical access, the fact that public transportation is accessible, there are curb cuts most places, most buildings are accessible, leads to a social acceptability. That somehow because there's physical access, there are simply more disabled people out and about in the world, and so people have learned how to interact with them and are used to them in a certain way. And so the physical access leads to a social access and acceptance" (Butler \& Taylor 2010: 1:35-2:22).
På så sätt kopplar Taylor ihop kroppslighet och diskurs. Tillgänglighet verkar på flera plan, och när normaternas värld tack vare den fysiska tillgängligheten invaderas av "(...) the array of deviant others whose marked bodies shore up the normate's boundaries" (Garland-Thomson 1997:8) så krackelerar den rena värld, fri från funktionsnedsättningar, som är förutsättningen för normatens ohotade maktposition. ${ }^{2}$

Könet. Det som slutligen cripteori kan göra är att (åter)insätta sexualiteten och könet i funktionshinderforskningen. Från att ha varit helt frånvarande 1980- och 1990-talens samhällsvetenskapliga och humanistiska funktionshinderforskning kan kön och sexualitet åter sättas i centrum genom cripteori och dess arv från queerteori. Tom Shakespeare, Kath Gillespie-Sells och Dominic Davies efterlyste redan 1996 ett större intresse från forskningshåll och aktivisthåll, men deras bok följdes inte av särskilt många andra. Men cripteorins fokus på sexualitet har ändå bidragit till flera skrifter som bryter tystnaden kring funktionshindrade människors sexuella uttryck (Shakespeare et al. 1996; Guter \& Killacky 2004; McRuer \& Mollow 2012). De som definierar sin forskning som critical disability studies eller feminist disability studies riskerar att förlora den dimension som uppmärksammar sexualiteten. Funktionshinderaktivisten Liz Crow, som tidigare prioriterat kampen för jobb, utbildning, boende och transporter, ser det som ett problem att sexualitet i alla sammanhang negligeras: "For the first time now I'm beginning to believe that sexuality, the one area above all others to have been ignored, is at the absolute core of what we're working for" (Crow i Shakespeare 2006: 183).

\section{CRIPTEORINS BEGRÄNSNINGAR}

Det som cripteori saknar, i McRuers version och i alla andra versioner jag sett, är att 
inkludera intellektuella funktionshinder och betona de starka funktionshindrade. $\mathrm{McRu}-$ ers egen bok ligger farligt nära att hylla en "super crip". Har han i likhet med "the social model" framhållit ett funktionshindrat subjekt som är autonomt och "beyond pain and failure" (Erevelles 2014; Hall 2015:3). Så mycket i cripteori handlar om aktörskap och autonomi att personer med behov av kognitiv assistans eller personer med signifikanta fysiska funktionsnedsättningar helt exkluderas (Kulick \& Rydström 2015; Löfgren-Mårtenson 2013). Ingenstans i Robert McRuers bok nämns intellektuella funktionsnedsättningar och inte heller i den volym om sexualitet och funktionshinder som han redigerat med Anne Mollow (McRuer \& Mollow 2012). Det är att bortse från en av de stora saker som hänt inom det praktiska arbetet och policydiskussionerna om funktionshinder. Typiskt för det arbetet är ju att intellektuella, psykiska och fysiska funktionshinder numera räknas till en och samma kategori. Den svenska och danska assistanslagen och den danska handboken om sexualitet och funktionshinder riktar sig till personer med olika typer av funktionsnedsättningar, inte bara fysiska. Diskrimineringslagstiftning och rättighetsdokument behandlar de olika typerna av funktionshinder $\mathrm{i}$ ett sammanhang men cripteori vänder sig enbart till personer med fysiska funktionsnedsättningar. Den dag cripteori kan uppvisa en inkluderande teori, som också kan hantera frågor om autonomi och kognitiv assistans kommer dess relevans att öka. Till dess kommer många forskare som är intresserade av att tänka kring funktionshinder, feminism och sexualitet att se på andra teoribildningar och forskningsansatser för inspiration.

\section{Jens Rydström, Professor Genuspetenskapliga institutionen Lunds Universitet}

\section{Noter}

1. Jag växlar mellan att skriva "personer med funktionsnedsättning”, som är en amerikansk standard, och "funktionshindrade personer", som är vad som oftast används i Storbritannien.

2. I Sverige saknas sådana städer, som är berömda för sin tillgänglighet, som Taylor talar om, medan Berkeley i USA och Århus i Danmark kan sägas vara ställen dit personer med funktionsnedsättning flyttar och bidrar till att göra dem ännu mer tillgängliga än den redan är.

\section{LITTERATUR}

- Kathryn Abrams (2011): Performing interdependence: Judith Butler and Sunaura Taylor in the Examined Life, i: Columbia Journal of Gender es Law, 21 (72). http://scholarship.law.berkeley.edu/facpubs/464. Åtkomst 30 september 2016.

- Begler, Ann-Marie (2015). "Vi tar krafttag mot fusket". Svenska Dagbladet, l oktober.

- Berg, Susanne (2004): Personal assistance and social reform according to the Swedish relative model of disability: A qualitative analysis of the 1994 reforms. University of Leeds, Leeds.

- Berg, Susanne (2004): 25 arr: Independent Living i Sverige. Johanneshov: STIL.

- Butler, Judith (1990): Gender trouble: Feminism and the subversion of identity. Routledge, New York.

- Butler, Judith \& Taylor, Sunaura (2010): Examined life. Youtube. Åtkomst 30 september 2016. https://www.youtube.com/watch?v=k0HZaP$\mathrm{kF} 6 \mathrm{qE}$

- Bylund, Christine (2016): Kuvande rum: Materialitet och funktionsfullkomlighet $i$ berättelser frän kvinnor uppväxta på institutioner för barn med normbrytande funktionalitet under 1930 till 1970talet. Masteruppsats i genusvetenskap, Stockholms universitet.

- Garland-Thomson, Rosemarie (1997): Extraordinary bodies: figuring physical disability in American culture and literature. Columbia University Press, New York.

. Guter, Bob \& Killacky, John R. (ed.) (2004): Queer crips: Disabled gay men and their stories. Harrington Park, New York.

- Erevelles, Nirmala (2014): Thinking with disability studies, in: Disability Studies Quarterly, 34, (2). http://dsq-sds.org/ Åtkomst 1 oktober 2016. . Hall, Kim Q. (2015): New conversations in femi- 
nist disability studies: Feminism, philosophy, and borders, in: Hypatia: A Journal of Feminist Philosophy, 30 (1), s. 2-12.

- Hall, Kim Q. (2015): Hypatia: A Journal of Feminist Philosophy (red). Special issue on Feminism, Disability, Borders, vol 30, no.1.

- Hoog, Helena, Agdalen, Tomas \& Birkelof, Lena (2015). Assistansersattningen: Brister i lagstiftning och tillampning. Stockholm: Inspektionen for socialforsakringen.

- Kafer, Alison (2013): Feminist queer crip. Indiana University Press, Bloomington and Indianapolis. - Kulick, Don \& Rydström, Jens (2015): Loneliness and its opposite: Sex, disability, and the ethics of engagement. Duke University Press, Durham.

. Löfgren-Mårtenson, Lotta (2013): “'Hip to be crip?": About crip theory, sexuality and people with intellectual disabilities" i: Sexuality and Disability, vol. 31, nr. 4, s. 413-424.

- McRuer, Robert (2005): "Miffoteori” i: Arena, 30 november.

- McRuer, Robert (2006). Crip theory: Cultural signs of queerness and disability. New York University Press, New York.

- McRuer, Robert \& Mollow, Anna (red., 2012): Sex and disability. Duke University Press, Durham. - Patsavas, Alyson (2014): "Recovering a cripistemology of pain", i: Journal of Literary and Cultural Disability Studies, vol. 8, nr. 2, s. 203-218.
- Rich, Adrienne (1980): "Compulsory Heterosexuality and Lesbian Existence", i: Signs, vol. 5, nr. 4, s. 631-660.

. Sandahl, Carrie (2003): "Queering the crip or cripping the queer? Intersections of queer and crip identities in solo autobiographical performance", $\mathrm{i}$ : GLQ: A journal of lesbian and gay studies, vol. 9, nr. 1-2, s 25-56.

. Sedgwick, Eve Kosofsky (1990): Epistemology of the closet. Berkeley, University of California Press. - Shakespeare, Tom (2006): Disability rights and wrongs. London, Routledge.

- Shakespeare, Tom, Kath Gillespie-Sells, \& Dominic Davies (1996): The sexual politics

of disability: Untold desires. London, Cassell. - Siebers, Tobin (2008): Disability theory. University of Michigan Press, Ann Arbor.

- Spade, Dean (2003): "Resisting medicine, re/modeling gender" i: Berkeley Women's Law Journal, vol. 18, s. 15-37.

- Warner, Michael (1994): Fear of a queer planet: Queer politics and social theory. (red.) Univ. of Minnesota Press, Minneapolis.

- Warner, Michael (1999): The trouble with normal: Sex, politics and the ethics of queer life. New York, Free Press.

. Wolmesjö, Maria \& Zanderin, Lars (red., 2009): LSS: Regelsystem, implementering och realitet. Lund, Studentlitteratur. 